International Journal of Agriculture, Environment and Bioresearch

Vol. 4, No. 05; 2019

ISSN: $2456-8643$

\title{
BIOLOGICAL EFFICIENCY OF MESOTRIONE 480 G/L AGAINST SUGAR CANE WEEDS (BIDENS PILOSA, AGERATUM CONYZOIDES, CYPERUS SPP.), IN BURKINA FASO
}

\author{
KAMBOU Georges ${ }^{1}$ and BIHOUN Mounkuy Cyprien ${ }^{2}$ \\ ${ }^{1}$ INERA FARAKOBA. Research Laboratory. PO. Box. 403. Bobo-Dioulasso. Burkina Faso. \\ ${ }^{2}$ Matourkou Polyvalent Agricultural Center, PO. Box 130. Bobo-Dioulasso
}

http://doi.org/10.35410/IJAEB.2019.4426

\begin{abstract}
A study of Amazing 480 SC (Mesotrione $480 \mathrm{~g} / \mathrm{l}$ ) biological efficiency against weeds (Bidens pilosa, Ageratum conyzoides, Cyperus spp., etc.) which caused big damage to sugar cane has been done at the site of SN-SOSUCO, sugar cane Company, in Burkina Faso. The experimental design was a completely randomized Fisher block of six treatments in four replications (untreated control, manual weeding, Chlorimuron-ethyl 250g/ha, Mesotrione $400 \mathrm{ml} / \mathrm{ha}$, Mesotrione $800 \mathrm{ml} / \mathrm{ha}$, Mesotrione $1333.33 \mathrm{ml} / \mathrm{ha}$ ). Weeds counting and dry biomass weighing have been done using a $0.25 \mathrm{~m} 2$ quadrant according to Likov and al. (1985) method. The biological efficiency coefficients have been evaluated using Vilitsky (1989) formula. The coefficients efficiency of the three rates of Mesotrione $480 \mathrm{~g} / 1$ varied from 62.01 to 100 according to their number of weeds and from 50.23 to 100 according to their dry biomass weight compared to the untreated control, during the sugar cane development. However, some weeds as Ageratum conyzoides, Mitracarpus villosus and Commelina benghalensis were resistant to different rates of Mesotrione $480 \mathrm{~g} / \mathrm{l}$. All these factors allowed to get, for the three rates of Mesotrione, respectively some yield increase of $178.70 \% ; 207.17 \%$ and $242.76 \%$ in comparison to the untreated control. The one of Chlorimuron-ethyl $250 \mathrm{~g} / \mathrm{ha}$ got an increase of $177.94 \%$ in comparison with the untreated control. For profitability' reasons, Mesotrione could be apply at the rate of $800 \mathrm{ml} / \mathrm{ha}$.
\end{abstract}

Keywords: Mesotrione, Chlorimuron-ethyl, weeds, sugar cane, Burkina Faso.

\section{INTRODUCTION}

Sugar cane (Saccharum officinarum) is a plant of the Poaceae family, produced for the sweet juice contained in its stem. This plant is the largest source of sugar production in the world (Kambou et al, 2015). According to Cirad (2017), more than one hundred (100) countries in the world, produce sugar cane plant for more than 1.80 billion tons of cane or about one hundred eighty (180) million tons of sugar. The largest producers are Brazil, India and the European Union, which alone produce more than half of the world's production. If the increase in sugar cane production is due to the increasing consumption needs of the population, the production of ethanol-based biofuel is another reason, especially since 50\% of Brazil's production is destined for this purpose (Cirad, 2017). Burkina Faso, although it remains a modest producer of sugar 
cane worldwide, intends to improve and increase its production in order to meet the increasingly demanding and growing local demand. Indeed, the New Sugar cane Society of Comoe (SNSOSUCO) established since 1965 has made this culture one of the jewels of the landscape of the waterfalls region in particular and of the country in general. For an estimated production of 30,000 tons of sugar per year, this company employs more than 3,000 employees, making it the Burkina Faso's largest private employer. This sugar cane production, however, remains, like other crops, subject in recent years to several attacks due to pests like the stalk borer Eldana saccharina (Lepidoptera: Pyralidae) (Goebel et al. (2003); white grubs as well as to weeds which cause enormous production losses. Weeds alone, if not controlled, can cause damage in the range of 30-40\% of sugar cane yields (Cirad, 2017). To reduce the harmful effects of these weeds, to an economically tolerable threshold, several means of control are used such as manual, mechanized and chemical weeding. Manual weeding has a dual role of weeding and improving soil structure, but is not always easy because it requires a very large workforce. Mechanized tillage, too, is not always an option due to soil destruction and its negative impact during the production process (Kambou et al, 2008). Notwithstanding the fact that poorly executed chemical control can lead to a severe ecological imbalance, it remains in the short term as a panacea, the best alternative to reduce the effect of weeds on food and industrial crops. For this reason, it is became necessary to study the biological efficacy of Amazing 480 SC (Mesotrione $480 \mathrm{~g} / \mathrm{l}$ ) on sugar cane weeds (Saccharum officinarum).

\section{MATERIAL AND METHODS}

\subsection{Material}

The plant material is sugar cane variety CO 997. It is the most produced variety on the sugar perimeter of SN SOSUCO with $36 \%$ of the area in 2018 but remains very sensitive to the weeds invasion. However, it has a very high state of plasticity (possibility of harvesting over a long period) with an average yield of 76 Tons of rods/ha (production department of SN SOSUCO, 2018). Plot plugging was carried out on the tractor with a disc plough followed by pulverizing and furrowing. A maintained pressure sprayer was used for the herbicides application in the plots to be treated. The young cuttings, from the nursery about six months old, are cut at intervals of two internodes and placed end to end in the furrows then closed by a light layer $(3$ to $5 \mathrm{~cm})$ of soil. Immediately after planting, the sampled herbicide treatments have been applied with REBEL $250 \mathrm{WG}$ (Chlorimuron-ethyl $250 \mathrm{~g} / \mathrm{l}$ ) at $250 \mathrm{~g} / \mathrm{ha}$ as a control herbicide and three rates of AMAZING $480 \mathrm{EC}$ (Mesotrione $480 \mathrm{~g} / \mathrm{l}$ ) as the experienced product. Mineral fertilization consisted of a fertilizer application of $500 \mathrm{~kg} / \mathrm{ha}$ of NPK (16-6-18) $+5 \mathrm{~S}+3 \mathrm{MgO}$ has been done in grooves before planting;

$65 \mathrm{~kg} / \mathrm{ha}$ of DAP (18-46-0) at 14 days after planting;

$150 \mathrm{~kg} / \mathrm{ha} \mathrm{KCl}(0-0-60)$ at 14 days after planting;

$148 \mathrm{~kg} / \mathrm{ha}$ of urea (46-0-0) at 45 days after planting. Cultivation technics are those applied by SN SOSUCO.

\subsection{Methods.}


The experimental design was a completely randomized Fisher block of six treatments in four replications. The treatments were: Untreated control, manual weeding, Chlorimuron-ethyl 250 $\mathrm{g} / \mathrm{ha}$, Mesotrione $400 \mathrm{ml} / \mathrm{ha}$, Mesotrione $800 \mathrm{ml} / \mathrm{ha}$, Mesotrione $1333.33 \mathrm{ml} / \mathrm{ha}$. The elementary plots are composed of 6 double-lines of $10.8 \mathrm{~m}$ long and $9.25 \mathrm{~m}$ wide or an area of $100 \mathrm{~m} 2$. The distance between the blocks was $1.5 \mathrm{~m}$ and $2.5 \mathrm{~m}$ between the objects.

\subsubsection{Phyto-toxicity.}

After herbicides application, the phyto-toxicity on sugar cane has been evaluated by a visual scale of 0 to 10 (method of the European Biological Assays Commission). This has been done based on observed plants alterations (AFPP-CEB., 2015).

\subsubsection{Effects of Mesotrione $480 \mathrm{~g} / \mathrm{l}$ on the sugar cane weeds number.}

The evaluation has been done by counting and grubbing weeds as soon as they appeared using a $0.25 \mathrm{~m} 2$ square placed around four strains at regular diagonal intervals, in each useful plot at the 7th, 15th, 30th, 45th, 65th, 90th and 120th day after herbicides application. The herbicide coefficients efficiency, in these periods, was evaluated using the Vilitsky formula, (1989) which is:

$\mathrm{C}=100-\mathrm{B} 0.100 / \mathrm{BK}$

Where:

$\mathrm{C}=$ coefficient efficacy of herbicides compared to untreated control;

$\mathrm{B} 0=$ number of weeds $($ feet $/ \mathrm{m} 2)$ or dry biomass weight $(\mathrm{g} / \mathrm{m} 2)$ on the treated plot;

$\mathrm{Bk}=$ number of weeds $($ feet $/ \mathrm{m} 2)$ or dry biomass weight $(\mathrm{g} / \mathrm{m} 2)$ on the untreated control plot.

\subsubsection{Effects of Mesotrione $480 \mathrm{~g} / \mathrm{l}$ on weeds dry biomass dynamic accumulation.}

It has been done by drying and then weighing the weeds dry biomass, during sugar cane phenological stages, according to LIKOV (1985) method.

\subsubsection{Effects of Mesotrione $480 \mathrm{~g} / \mathrm{l}$ different rates on sugar canes weeds flora.}

The identification of the different weeds have been done using Terry (1983) and Akobundu et al. (1982) keys.

\subsubsection{Effects of Mesotrione $480 \mathrm{~g} / \mathrm{l}$ on sugar cane development.}

The number of productive tillers and machinable canes have been also evaluated at 2, 3, 4 months after herbicides applications. This allowed studying the herbicides impact on sugar cane development.

\subsubsection{Statistical analysis.}


The obtained data were submitted to variance analysis (Dospiehov., 1985) at the 5\% threshold, followed by Newman-Keuls test, using Genstat software. Means of the number and weight of dry biomass of weeds were previously transformed by the $\mathrm{V}-\mathrm{x}+1$ formula before being analyzed to reduce the large variability between the collected data. The correlations between some studied parameters were made using XLSTAT 2015 version software. Software such as Microsoft Word 2016 and Excel 2016 have been also used for text entry and table development

\section{RESULTS}

\subsection{Phyto-toxicity of different rates of Mesotrione $480 \mathrm{~g} / \mathrm{l}$ on sugar cane.}

During the observations, there are no phyto-toxicity symptoms from Amazing 480 SC, on treated sugar cane plants compared to those of the untreated control.

\subsection{Effects of different rates of Mesotrione $480 \mathrm{~g} / \mathrm{l}$ on sugar cane weeds number.}

At the 7th day after application, there was homogeneity of weed population in all treatments. The average effect of herbicides ( 1 foot $/ \mathrm{m} 2)$ therefore represents a $100 \%$ reduction in the number of weeds compared to the untreated control and the control product (Table I).

At the 15th day after insecticides application, there is a significant difference between the different objects. The average effect of herbicides $(1 \mathrm{foot} / \mathrm{m} 2)$ represents weeds reduction of $84.69 \%$ compared to the untreated control and $81.79 \%$ compared to the control herbicide chlorimuron-ethyl.

. At the 30th day, after herbicides application, the high and average rates of Mesotrione $480 \mathrm{~g} / \mathrm{l}$, do not differ from each other and from the control product. The average herbicides effect (2.79 feet $/ \mathrm{m} 2$ ) is a reduction of $78.00 \%$ in comparison with the untreated control. However, manual weeding treatment was more efficient with $92.11 \%$ reduction in comparison with the untreated control and a $32.89 \%$ reduction from the high rate of Mesotrione $480 \mathrm{~g} / \mathrm{l}$. The average rate, Mesotrione $400 \mathrm{ml} / \mathrm{ha}$, was $76.10 \%$ lower than the untreated control.

At the 45th day after application, the average effect of herbicides (4.90 feet/ha) is a weeds reduction of $65.97 \%$ compared to the untreated control. However, there is no significant difference between the manual weeding and the low rate of Mesotrione $480 \mathrm{~g} / \mathrm{l}$. The rate of Amazing $1333.33 \mathrm{ml} / \mathrm{ha}$ appears to be the most effective with a weed reduction of $70.83 \%$ compared to the untreated control.

At the 65th day after herbicides application, the average effect of herbicides $(6.31 \mathrm{feet} / \mathrm{m} 2)$ is a weeds reduction of $57.39 \%$ compared to the untreated control. There is no significant difference between the low rate of Mesotrione $480 \mathrm{~g} / \mathrm{l}$ and the manual weeding. However, Mesotrione $1333.33 \mathrm{ml} / \mathrm{ha}$ is more efficient with a reduction of $63.54 \%$ compared to the untreated control and of $35.56 \%$ compared to the manual weeding.

At the 90th day after treatment, there is a significant difference between the treatments. The average effect of herbicides $(5.06 \mathrm{feet} / \mathrm{m} 2)$ is a weeds reduction of $51.06 \%$ compared to the untreated control. There is no significant difference between Chlorimuron-ethyl $250 \mathrm{~g} / \mathrm{l}$, 
Mesotrione $400 \mathrm{ml} / \mathrm{ha}$ and Mesotrione $800 \mathrm{ml} / \mathrm{ha}$. However, the control product which appears to be most effective shows a weeds reduction of $60.44 \%$ compared to the untreated control and of $29.85 \%$ compared to the manual weeding.

At the 120th day after application, the same trends were observed on all treatments. The average effect of herbicides $(4.80 \mathrm{feet} / \mathrm{m} 2)$ is a weeds reduction of $50.92 \%$ compared to the untreated control. There is no significant differences between manual weeding, Mesotrione $400 \mathrm{ml} / \mathrm{ha}$, Mesotrione $800 \mathrm{ml} / \mathrm{ha}$ and Chlorimuron - ethyl $250 \mathrm{~g} / \mathrm{ha}$. 
Table 1: Affects of different rates of Mesotrione $480 \mathrm{~g} / \mathrm{l}$ on sugar cane weeds number (feet $/ \mathrm{m} 2)$.

\begin{tabular}{|c|c|c|c|c|c|c|c|c|c|c|c|c|c|c|}
\hline \multirow{3}{*}{ Treatments } & \multicolumn{14}{|c|}{ Observations periods (DAA = Day After Application) } \\
\hline & \multicolumn{2}{|c|}{7} & \multicolumn{2}{|c|}{15} & \multicolumn{2}{|c|}{30} & \multicolumn{2}{|c|}{45} & \multicolumn{2}{|c|}{65} & \multicolumn{2}{|c|}{90} & \multicolumn{2}{|c|}{120} \\
\hline & $\begin{array}{c}\text { No } \\
\text { trans. }\end{array}$ & $\begin{array}{c}\text { After } \\
\sqrt{ }_{x}+1\end{array}$ & $\begin{array}{c}\text { No } \\
\text { trans. }\end{array}$ & $\begin{array}{l}\text { After } \\
\sqrt{x}+1\end{array}$ & $\begin{array}{c}\text { No } \\
\text { trans. }\end{array}$ & $\begin{array}{l}\text { After } \\
\sqrt{x}+1\end{array}$ & $\begin{array}{l}\text { No } \\
\text { trans. }\end{array}$ & $\begin{array}{c}\text { After } \\
\sqrt{x}+1\end{array}$ & $\begin{array}{c}\text { No } \\
\text { trans. }\end{array}$ & $\begin{array}{c}\text { After } \\
\sqrt{x}_{\mathbf{x}}+1\end{array}$ & $\begin{array}{c}\text { No } \\
\text { trans. }\end{array}$ & $\begin{array}{l}\text { After } \\
\sqrt{x}+1\end{array}$ & $\begin{array}{c}\text { No } \\
\text { Trans. }\end{array}$ & $\begin{array}{c}\text { After } \\
\sqrt{ } \mathbf{x}+1\end{array}$ \\
\hline Control & 0.00 & 1.00 & 49.00 & $6.53 a$ & 175.75 & 12.68a & 210.25 & $14.40 a$ & 222.25 & 14.81a & 107.80 & $10.34 a$ & 94.75 & $9.78 \mathrm{a}$ \\
\hline Manual weeding & 0.00 & 1.00 & 32.25 & $5.49 b$ & 0.00 & $1.00 b$ & 39.25 & $6.15 b$ & 71.50 & $8.38 b$ & 35.50 & $5.83 \mathrm{bc}$ & 26.50 & $5.17 b c$ \\
\hline Chlo- ethyl $250 \mathrm{~g} / \mathrm{ha}$ & 0.00 & 1.00 & 0.00 & $1.00 \mathrm{c}$ & 6.25 & $2.60 \mathrm{c}$ & 24.00 & $4.56 c$ & 31.25 & $5.65 \mathrm{c}$ & 16.25 & 4.09d & 18.50 & $4.33 c$ \\
\hline Mesotrione $400 \mathrm{ml} / \mathrm{ha}$ & 0.00 & 1.00 & 0.00 & $1.00 \mathrm{c}$ & 16.00 & 4.04d & 41.50 & $6.17 b$ & 59.50 & $7.77 b$ & 39.50 & $6.29 b$ & 36.00 & $5.97 b$ \\
\hline Mesotrione $800 \mathrm{ml} / \mathrm{ha}$ & 0.00 & 1.00 & 0.00 & $1.00 \mathrm{c}$ & 10.00 & $3.03 c$ & 24.75 & $4.67 c$ & 41.00 & $6.43 c$ & 25.50 & $5.04 \mathrm{~cd}$ & 22.25 & 4.71c \\
\hline Mesotri. $1333,3 \mathrm{ml} / \mathrm{ha}$ & 0.00 & 1.00 & 0.00 & $1.00 c$ & 1.50 & $1.49 b$ & 17.50 & $4.20 \mathrm{c}$ & 31.50 & $5.40 \mathrm{c}$ & 24.25 & 4.81d & 17.00 & $4.20 \mathrm{c}$ \\
\hline Average & & 1.00 & & 2.67 & & 4.14 & & 6.70 & & 8.08 & & 6.07 & & 5.69 \\
\hline $\mathrm{CV}(\%)$ & & 0.00 & & 7.70 & & 8.20 & & 7.50 & & 9.40 & & 9.10 & & 10.30 \\
\hline Sed $(\mathrm{df}=15)$ & & 0.00 & & 0.21 & & 0.34 & & 0.50 & & 0.76 & & 0.55 & & 0.29 \\
\hline e.s.e (Sx) & & 0.00 & & 0.10 & & 0.17 & & 0.25 & & 0.38 & & 0.26 & & 0.59 \\
\hline
\end{tabular}

N.B: no trans. = number without transformation.

\section{Biological efficiency coefficients of Mesotrione $480 \mathrm{~g} / \mathrm{l}$ different rates, according to the number of weeds.}

The coefficients efficiency of manual weeding varied between 24.76 to quantity of extractible sugar 100 with an average of 70.98. The highest coefficients were observed at the 7th and 30th day after treatment and the lower coefficient is situated at the 22th day after observations (table 2).

Chlorimuron - ethyl $250 \mathrm{~g} / \mathrm{ha}$ coefficients efficiency varied from 85.14 to 100 with an average of 92.87 . The best coefficients were obtained at the 7th, 15th day after application and the lowest coefficient was observed at the 12 0th day after treatment. It presents with the high dose of Amazing, the highest averages of coefficients efficiency between all treatments.

With an average of 85.13 , the coefficients of Mesotrione $400 \mathrm{ml} /$ ha varied from 62.01 to 100 . The coefficients of Mesotrione 800 $\mathrm{ml} / \mathrm{ha}$ varied between 76.52 and 100 with an average of 90.74 . The highest coefficients were at the 7 th and at the 15 th day after herbicides application and the lowest were situated at 120th day of observation.

The efficiency coefficients of Mesotrione $1333.33 \mathrm{ml} / \mathrm{ha}$ varied between 82.10 and 100 with an average of 92.23 . It has the highest average coefficient efficiency between the treatments.

Table 3: Biological efficiency coefficients of Mesotrione $480 \mathrm{~g} / \mathrm{l}$ different rates according to the number of weeds.

\begin{tabular}{|c|c|c|c|c|c|c|c|c|}
\hline \multirow{2}{*}{\multicolumn{2}{|c|}{ Treatments }} & \multicolumn{7}{|c|}{ Observations periods (DAA = Day After Application) } \\
\hline & & 7 & 15 & 30 & 45 & 65 & 90 & 120 \\
\hline \multicolumn{2}{|c|}{ Untreated control } & - & - & - & - & - & _ & - \\
\hline \multicolumn{2}{|c|}{ Manual weeding } & 100.00 & 34.18 & 100.00 & 81.33 & 65.99 & 83.12 & 72.03 \\
\hline \multicolumn{2}{|c|}{ Chlorimuron - ethyl $250 \mathrm{~g} / \mathrm{ha}$} & 100.00 & 100.00 & 96.44 & 88.59 & 85.14 & 92.27 & 80.48 \\
\hline Mesotrione & $400 \mathrm{ml} / \mathrm{ha}$ & 100.00 & 100.00 & 90.90 & 80.26 & 71.70 & 81.21 & 62.01 \\
\hline Mesotrione & $800 \mathrm{ml} / \mathrm{ha}$ & 100.00 & 100.00 & 94.31 & 88.23 & 80.50 & 87.87 & 76.52 \\
\hline Mesotrione & $1333,3 \mathrm{ml} / \mathrm{ha}$ & 100.00 & 100.00 & 99.15 & 91.68 & 85.02 & 88.47 & 82.10 \\
\hline
\end{tabular}

\subsection{Affects of Mesotrione $480 \mathrm{~g} / \mathrm{l}$ different rates on weeds flora.}

At the 90th JAT, the weeds flora of the experimental test is diversified. In fact, the inventory carried out at this date shows twelve (12) species found in seven (7) botanical families (Table 3).

The most commonly evaluated species are Ageratum conizoides, Bidens pilosa, Commelina bengalensis, Cyperus ssp and Mitracarpu s villosus. Other families of weeds appeared but in relatively small numbers.

The most important floristic diversity was found in the untreated control, manual weeding and Mesorione $400 \mathrm{ml} / \mathrm{ha}$, each of which had nine (9) species, followed by the control product with eight (8) species, finally the recommended and high dose. Mesotrione has shown the smallest diversities with each six (6) species of weeds.

According to their density, the untreated control with $107.5 \mathrm{feet} / \mathrm{m}^{2}$ has the highest weed density with a predominance of Asteraceae (Bidens pilosa and Ageratum conyzoides) for $91.63 \%$ of weeds.

The manual weeding with 35.5 feet $/ \mathrm{m}^{2}$ also displays the same trends as the untreated control. The predominant species are mainly Bidens pilosa with $68.31 \%$ and Ageratum conyzoides with $21.13 \%$ of weeds. No less important species such as Kyllinga pumila (2.82\%) and Cyperus sp. (2.11\%) also exist. 
In the plots of the control product (Chlorimuron -ethyl 250g / ha), eight (8) species in six (6) botanical families were counted. The most abundant species is Ageratum conizoides with 44, 62\% of weeds then, comes Commelina benghalensis with 16, 92\% of weeds..

In the plots treated with Mesotrione at the rate of $400 \mathrm{ml} /$ ha, nine (9) species distributed in six (6) families were identified during the inventory. Ageratum conizoides is the most common species in these plots and constitutes $31.01 \%$ of their number. Commelina benghalensis and Mitracarpus vilosus each have $22.78 \%$ of the weeds counted. However, this treatment has reduced the number of Ageratum conizoides by 15.65 times compared to the untreated control, but remains ineffective against Commelina benghalensis and Mitracarpus villosus where there is a significant increase in the number of weeds (12 times) compared to the untreated control.

In the plots treated with Mesotrione $800 \mathrm{ml} / \mathrm{ha}$, six (6) species belonging to four (4) botanical families are observed. Ageratum conizoides is still the most abundant species according to the relative inventory with $38.00 \%$, then comes Mitracarpus vilosus with $30.00 \%$, then Commelina benghalensis with $17.00 \%$ of weeds. This dose of Mesotrione had an influence on the Bidens pilosa species with a significant reduction compared to the untreated control.

In the plots treated with Mesotrione $1333.33 \mathrm{ml} / \mathrm{ha}$, six (6) species of four (4) botanical families were counted during the inventory. The dominant species is M. vilosus with $26.04 \%$ followed by Cyperus sp. with $19.79 \%$ and finally C. benghalensis with $15.63 \%$ of weeds.

Table 3. Effects of Mesotrione $480 \mathrm{~g} / \mathrm{l}$ different rates on sugar canes weeds flora.

\begin{tabular}{|c|c|c|c|c|c|c|c|}
\hline Genus Species & Families & $\begin{array}{c}\text { Untreated } \\
\text { control }\end{array}$ & $\begin{array}{r}\text { Manual } \\
\text { weeding }\end{array}$ & $\begin{array}{c}\text { Chlorimuron } \\
250 \text { g/ha }\end{array}$ & $\begin{array}{l}\text { Mesotrione } \\
400 \mathrm{ml} / \mathrm{ha}\end{array}$ & $\begin{array}{c}\text { Mesotrione } \\
800 \mathrm{ml} / \mathrm{ha}\end{array}$ & $\begin{array}{c}\text { Mesotrione } \\
1333.3 \mathrm{ml} / \mathrm{ha}\end{array}$ \\
\hline Ageratum conyzoides & Asteraceae & 34 & 30 & 29 & 49 & 38 & 25 \\
\hline Bidens pilosa & Asteraceae & 360 & 97 & 9 & 23 & 6 & 9 \\
\hline Cleome rutidosperma & Cleomaceae & 2 & 0 & 1 & 0 & 0 & 0 \\
\hline Commelina benghalensis & Commelinaceae & 3 & 2 & 11 & 36 & 17 & 15 \\
\hline Cyperus ssp & Cyperaceae & 11 & 3 & 6 & 3 & 6 & 19 \\
\hline Digitaria horizontalis & Poaceae & 0 & 1 & 6 & 1 & 0 & 0 \\
\hline Eleusine indica & Poaceae & 8 & 2 & 0 & 1 & 0 & 0 \\
\hline Ipomoea involucrata & Convolvulaceae & 0 & 0 & 0 & 1 & 0 & 0 \\
\hline Kyllinga pumila & Cyperaceae & 0 & 4 & 0 & 0 & 0 & 0 \\
\hline Mitracarpus villosus & Rubiaceae & 3 & 0 & 1 & 36 & 30 & 25 \\
\hline Oldenlandia corymbosa & Rubiaceae & 6 & 1 & 2 & 8 & 3 & 3 \\
\hline Pycreus lanceolatus & Cyperaceae & 3 & 2 & 0 & 0 & 0 & 0 \\
\hline Total & & 430 & 142 & 65 & 158 & 100 & 96 \\
\hline Mean & & 107.50 & 35.50 & 16.25 & 39.50 & 25.00 & 24.00 \\
\hline
\end{tabular}

\subsection{Effects of different rates of Mesotrione $480 \mathrm{~g} / \mathrm{l}$ on sugar cane weeds dry biomass.}

At the 7th day after application of herbicides, there is no significant difference between the different treatments including untreated control and manual weeding at the $5 \%$ level by the Newman-Keuls test (Table 4 ).

At the 15th day after herbicides application, the average herbicide effect $(1 \mathrm{~g} / \mathrm{m} 2)$ is a reduction of $64.41 \%$ dry biomass weight compared to the untreated control. However the different rates of Mesotrione 480 SC do not differ from each other and from the control product. The manual weeding $(2.38 \mathrm{~g} / \mathrm{m} 2)$ represents a $15.30 \%$ reduction in dry biomass compared to the untreated control.

At the 30th day after application, the average herbicide effect $(2.17 \mathrm{~g} / \mathrm{m} 2)$ is a dry biomass reduction of $70.75 \%$ compared to the untreated control. There is no significant difference between the control product and the average dose Mesotrione $400 \mathrm{ml} / \mathrm{ha}$. However, manual weeding $(1 \mathrm{~g} / \mathrm{m} 2)$ was more effective with an $86.52 \%$ reduction of weed dry biomass compared to the untreated control.

At the 45th day after application, the same trends are observed between the different treatments at the level of 5\% by Newman Keuls test. The average herbicide effect $\left(3.85 \mathrm{~g} / \mathrm{m}^{2}\right)$ is a $71.33 \%$ reduction in the amount of dry biomass compared to untreated control. There is no significant difference between the high and average doses of Mesotrione $480 \mathrm{~g} / \mathrm{l}$ and the control product. However Mesotrione $1333.33 \mathrm{ml} / \mathrm{ha}$ is more effective with a reduction rate of $77.59 \%$ compared to the untreated control. Manual weeding represents a $63.29 \%$ reduction in dry biomass compared to the untreated control.

At the 65th day after application, there was also a significant difference between the objects. The average herbicide effect $(8.77 \mathrm{~g} / \mathrm{m} 2)$ is a $60.62 \%$ reduction of dry biomass compared to the untreated control. There is no difference between the manual weeding and Mesotrione $200 \mathrm{ml} / \mathrm{ha}$. However Mesotrione $1333.33 \mathrm{ml} / \mathrm{ha}$ appears to be the most efficient with a reduction of $68.84 \%$ compared to the untreated control and of $41.34 \%$ compared to the manual weeding 
Table 4: Affects of different rates of Mesotrione $480 \mathrm{~g} / \mathrm{l}$ on the weight of sugar cane weeds dry biomass $\left(\mathrm{g} / \mathrm{m}^{2}\right)$.

\begin{tabular}{|c|c|c|c|c|c|c|c|c|c|c|c|c|c|c|}
\hline \multirow{3}{*}{ Treatments } & \multicolumn{14}{|c|}{ Observations periods (DAA = Day After Application) } \\
\hline & \multicolumn{2}{|c|}{7} & \multicolumn{2}{|c|}{15} & \multicolumn{2}{|c|}{30} & \multicolumn{2}{|c|}{45} & \multicolumn{2}{|c|}{65} & \multicolumn{2}{|c|}{90} & \multicolumn{2}{|c|}{120} \\
\hline & $\begin{array}{l}\text { No } \\
\text { trans. }\end{array}$ & $\begin{array}{c}\text { After } \\
\sqrt{ } \mathbf{x}+1\end{array}$ & $\begin{array}{l}\text { No } \\
\text { trans }\end{array}$ & $\begin{array}{c}\text { After } \\
\sqrt{\mathbf{x}}+\mathbf{1}\end{array}$ & $\begin{array}{l}\text { No } \\
\text { trans. }\end{array}$ & $\begin{array}{c}\text { After } \\
\sqrt{\mathbf{x}}+\mathbf{1}\end{array}$ & $\begin{array}{l}\text { No } \\
\text { trans }\end{array}$ & $\begin{array}{c}\text { After } \\
\sqrt{ } \mathbf{x}+1\end{array}$ & $\begin{array}{l}\text { No } \\
\text { trans }\end{array}$ & $\begin{array}{c}\text { After } \\
\sqrt{ } \mathbf{x}+1\end{array}$ & $\begin{array}{l}\text { No } \\
\text { trans. }\end{array}$ & $\begin{array}{c}\text { After } \\
\sqrt{ } \mathbf{x}+1\end{array}$ & $\begin{array}{l}\text { No } \\
\text { trans }\end{array}$ & $\begin{array}{c}\text { After } \\
\sqrt{\mathbf{x}}+\mathbf{1}\end{array}$ \\
\hline Control & 0.00 & 1.00 & 7.12 & 2.81a & 63.63 & $7.42 \mathrm{a}$ & 187.53 & 13.43a & 519.23 & $22.27 a$ & 581.25 & 22.63a & 268.05 & $16.35 a$ \\
\hline Manual weeding & 0.00 & 1.00 & 5.04 & $2.38 b$ & 0.00 & 1.00d & 24.79 & 4.93b & 159.67 & $11.83 b$ & 113.12 & $9.90 b$ & 8.79 & $3.12 d$ \\
\hline Chlorim-Ethyl $250 \mathrm{~g} / \mathrm{ha}$ & 0.00 & 1.00 & 0.00 & $1.00 \mathrm{c}$ & 4.97 & $2.17 \mathrm{c}$ & 10.16 & $3.28 \mathrm{c}$ & 61.80 & $7.75 \mathrm{~cd}$ & 71.60 & $7.53 \mathrm{c}$ & 34.08 & $5.39 \mathrm{c}$ \\
\hline Mesotrione $\quad 400 \mathrm{ml} / \mathrm{ha}$ & 0.00 & 1.00 & 0.00 & $1.00 c$ & 10.78 & 3.13b & 27.42 & $5.12 b$ & 147.89 & $11.81 b$ & 169.29 & 12.70d & 133.41 & $9.81 b$ \\
\hline Mesotrione $\quad 800 \mathrm{ml} / \mathrm{ha}$ & 0.00 & 1.00 & 0.00 & $1.00 \mathrm{c}$ & 3.92 & $2.17 \mathrm{c}$ & 16.50 & 3.99bc & 75.04 & $8.56 c$ & 71.13 & $8.05 c$ & 43.52 & $6.14 c$ \\
\hline Mesotrione $1333,3 \mathrm{ml} / \mathrm{ha}$ & 0,00 & 1.00 & 0.00 & $1.00 \mathrm{c}$ & 0.53 & $1.20 \mathrm{~d}$ & 9.08 & 3.01c & 66.45 & $6.94 d$ & 59.37 & $7.14 c$ & 31.56 & $5.07 \mathrm{c}$ \\
\hline Mean & & 1.00 & & 1.53 & & 2.85 & & 5.63 & & 11.53 & & 11.33 & & 7.65 \\
\hline $\mathrm{CV}(\%)$ & & 0.00 & & 17.30 & & 12.10 & & 11.20 & & 6.80 & & 9.10 & & 9.60 \\
\hline S.e.d $(\mathrm{df}=15)$ & & 0.00 & & 0.27 & & 0.34 & & 0.63 & & 0.78 & & 1.03 & & 0.74 \\
\hline e.s.e $(\mathrm{Sx})$ & & 0.00 & & 0.13 & & 0.17 & & 0.32 & & 0.39 & & 0.51 & & 0.37 \\
\hline
\end{tabular}


At the 90th day after application, the average herbicide effect $\left(8.86 \mathrm{~g} / \mathrm{m}^{2}\right)$ is a reduction of $60.84 \%$ in comparison with the untreated control. There is no significant difference between Mesotione $400 \mathrm{ml} / \mathrm{ha}$, Mesotrione $1333.33 \mathrm{ml} / \mathrm{ha}$, and Chlorimuron-ethyl 250g/ha. However Mesotrione $1333.33 \mathrm{ml} / \mathrm{ha}$ is the most efficient with a dry biomass reduction rate of $68.45 \%$ compared to the untreated control and of $27.88 \%$ compared to manual weeding. The control product, on the other hand, had a reduction in dry biomass weight of $66.73 \%$ compared to the untreated control.

At the 120th day after herbicides application, the average herbicide effect $\left(6.60 \mathrm{~g} / \mathrm{m}^{2}\right)$ is a reduction of $59.63 \%$ compared to the untreated control. There is no significant difference between the average, the high doses of the tested product and with the control product. However Mesotrione $1333.33 \mathrm{ml} / \mathrm{ha}$ is the most efficient with a dry biomass reduction of $69.00 \%$ compared to the untreated control.

3.6. Biological efficiency coefficients of the different rates of Mesotrione $480 \mathrm{~g} / \mathrm{l}$ according to weeds dry biomass.

The manual weeding coefficients varied from 8.27 to 100 with an average of 68.12 (Table 5). The coefficients of chlorimuron - ethyl varied from 84.03 to 100 with an average of 92.41. Those of Mesotrione $400 \mathrm{ml} / \mathrm{ha}$ dose varied from 50.23 to 100 with an average of 74.82 . The coefficients of Mesotrione $800 \mathrm{ml} /$ ha varied from 74.07 to 100.00 with an average of 78.44 .

The coefficients of Mestrione $1333.33 \mathrm{ml} /$ ha varied from 85.73 to 100 with an average 92.57 .

Table 5: Biological efficiency coefficients of the different rates of Mesotrione $480 \mathrm{~g} / \mathrm{l}$ according to weeds dry biomass.

\begin{tabular}{|c|c|c|c|c|c|c|c|c|}
\hline \multirow{2}{*}{\multicolumn{2}{|c|}{ Treatments }} & \multicolumn{7}{|c|}{ Observations periods (DAA = Day After Application) } \\
\hline & & 7 & 15 & 30 & 45 & 65 & 90 & 120 \\
\hline \multirow{3}{*}{\multicolumn{2}{|c|}{$\begin{array}{l}\text { Untreated control } \\
\text { Manual weeding } \\
\text { Chlorimuron-ethyl } 250 \mathrm{~g} / \mathrm{ha}\end{array}$}} & & - & - & & & & \\
\hline & & 100.00 & 29.20 & 100.00 & 61.05 & 69.25 & 80.54 & 96.72 \\
\hline & & 100.00 & 100.00 & 92.18 & 84.03 & 88.10 & 87.68 & 87.29 \\
\hline Mesotrione & $400 \mathrm{ml} / \mathrm{ha}$ & 100.00 & 100.00 & 83.06 & 56.91 & 71.52 & 70.88 & 50.23 \\
\hline Mesotrione & $800 \mathrm{ml} / \mathrm{ha}$ & 100.00 & 100.00 & 93.84 & 74.07 & 85.55 & 87.76 & 83.76 \\
\hline Mesotrione & $1333,3 \mathrm{ml} / \mathrm{ha}$ & 100.00 & 100.00 & 99.17 & 85.73 & 87.20 & 89.79 & 88.22 \\
\hline
\end{tabular}

\subsection{Effects of different doses of Amazing $480 \mathrm{SC}$ on sugar cane tillers development.}

Seedling emergence occurred around the 15th day of observation. At this stage, the average effect of herbicides (10.99 tillers $/ \mathrm{m}^{2}$ ) corresponds to an increase of $33.21 \%$ in tillers compared with the untreated control and $12.72 \%$ compared to manual weeding. There is no significant difference between the low and high doses of the experimented product (Table 6).

At the 30th day, the average effect of herbicides (17.69 tillers $/ \mathrm{m}^{2}$ ) corresponds to a $24.14 \%$ increase of tillers compared to the untreated control. There is not a significant difference between all treatments and the control except the recommended dose which shows a tillers increase rate of $40.35 \%$ compared to the untreated control.

At $45^{\text {th }}$ day, the average effect of herbicides (36.81 tillers $/ \mathrm{m}^{2}$ ) corresponds to an increase of $116.53 \%$ compared to the untreated control. Mesotrione $800 \mathrm{ml} / \mathrm{ha}$ and $1333.33 \mathrm{ml} / \mathrm{ha}$ got the 
largest numbers of tillers respectively $39.25 \mathrm{~m}^{2}$ and 40.00 tillers $/ \mathrm{m}^{2}$. The manual weeding which is not different with Chlorimuron-ethyl showed an increase of $94.12 \%$ in comparison with the untreated control.

At 65th day the average effect of herbicides $\left(48.19\right.$ tillers $\left./ \mathrm{m}^{2}\right)$ is an increase of $109.52 \%$ compared to the untreated control. The high dose of Mesotrione $480 \mathrm{SC}$ and the control product showed the highest number of tillers $\left(49.75\right.$ tillers $\left./ \mathrm{m}^{2}\right)$, which corresponds to an increase of $116.30 \%$ compared to the untreated control.

Table 6: Effects of Mesotrione $480 \mathrm{~g} / \mathrm{l}$ different rates on sugar cane development $\left(\right.$ tillers $\left./ \mathbf{m}^{2}\right)$.

\begin{tabular}{|c|c|c|c|c|c|c|}
\hline \multirow{2}{*}{\multicolumn{2}{|c|}{ Treatments }} & \multicolumn{5}{|c|}{ Observations periods (DAA = Day After Application) } \\
\hline & & 7 & 15 & 30 & 45 & 65 \\
\hline \multicolumn{2}{|c|}{ Untreated control } & 0.00 & $8.25 \mathrm{a}$ & $14.25 \mathrm{c}$ & $17.00 \mathrm{~d}$ & $23.00 \mathrm{c}$ \\
\hline \multicolumn{2}{|c|}{ Manual weeding } & 0.00 & $9.75 \mathrm{~b}$ & $16.00 \mathrm{~b}$ & $33.00 \mathrm{c}$ & $43.50 \mathrm{~b}$ \\
\hline \multicolumn{2}{|c|}{ Chlorimuron - ethyl $250 \mathrm{~g} / \mathrm{ha}$} & 0.00 & $9.50 \mathrm{~b}$ & $16.75 \mathrm{~b}$ & $33.00 \mathrm{c}$ & $49.75 \mathrm{a}$ \\
\hline Mesotrione & $400 \mathrm{ml} / \mathrm{ha}$ & 0.00 & $12.00 \mathrm{c}$ & $17.00 \mathrm{~b}$ & $35.00 \mathrm{~b}$ & $47.00 \mathrm{ab}$ \\
\hline Mesotrione & $800 \mathrm{ml} / \mathrm{ha}$ & 0.00 & $10.75 \mathrm{~d}$ & $20.00 \mathrm{a}$ & $39.25 \mathrm{a}$ & $46.25 \mathrm{ab}$ \\
\hline Mesotrione & $1333.3 \mathrm{ml} / \mathrm{ha}$ & 0.00 & $11.75 \mathrm{c}$ & $17.00 \mathrm{~b}$ & $40.00 \mathrm{a}$ & $49.75 \mathrm{a}$ \\
\hline \multicolumn{2}{|l|}{ Mean } & 0.00 & 10.33 & 16.83 & 32.88 & 43.21 \\
\hline \multicolumn{2}{|c|}{$\mathrm{CV}(\%)$} & 0.00 & 5.80 & 6.80 & 4.50 & 4.60 \\
\hline \multicolumn{2}{|c|}{ S.e.d $(\mathrm{df}=15)$} & 0.00 & 0.60 & 1.15 & 1.49 & 1.98 \\
\hline \multicolumn{2}{|c|}{ e.s.e $(\mathrm{Sx})$} & 0.00 & 0.30 & 0.60 & 0.75 & 0.99 \\
\hline
\end{tabular}

\subsection{Effects of the different rates of Mesotrione $480 \mathrm{~g} / \mathrm{l}$ on sugar cane yield components and yield.}

The manual weeding showed an increase in the number of machinable rods by $54.64 \%$ compared to the untreated control (Table 7).

Mesotrione $400 \mathrm{ml} /$ ha, for its part, showed a machinable cane increase of $42.14 \%$ compared to the untreated control. Mesotrione $800 \mathrm{ml} /$ ha led 55.64\%. The higher rate of Mesotrione is an increase of $60.76 \%$ over the untreated control. This is not so different with Chlrimuron-ethyl 250 $\mathrm{g} / \mathrm{ha}$. According to the yield, the average affect of herbicides $(61.47 \mathrm{~T} / \mathrm{ha})$ is an increase of $210.30 \%$ in comparison with the untreated control and of $11.64 \%$ in comparison with manual weeding. 
Table7: Effects of Mesotrione $480 \mathrm{~g} / \mathrm{l}$ different rates on sugar cane yield components and the yield.

\begin{tabular}{|c|c|c|c|c|c|}
\hline \multirow[t]{2}{*}{ Treatments } & \multicolumn{2}{|c|}{$\begin{array}{l}\text { Number of } \\
\text { machinables rods } \\
\text { (number/useful plot) }\end{array}$} & \multirow[t]{2}{*}{$\begin{array}{l}\text { Yield } \\
\text { (T/ha) }\end{array}$} & \multirow{2}{*}{$\begin{array}{l}\text { Quantity of } \\
\text { extractible } \\
\text { sugar } \\
\text { (T/ha) }\end{array}$} & \multirow[t]{2}{*}{$\begin{array}{l}\text { Sucrose } \\
\text { content } \\
(\%)\end{array}$} \\
\hline & $\begin{array}{l}\text { Without } \\
\text { Transf. }\end{array}$ & $\begin{array}{c}\text { After } \\
\sqrt{x}_{\mathbf{x}}+\mathbf{1}\end{array}$ & & & \\
\hline $\begin{array}{l}\text { Untreated control } \\
\text { Manual weeding } \\
\text { Clorimuron - ethyl } 250 \mathrm{~g} / \mathrm{ha} \\
\text { Mesotrione } 400 \mathrm{ml} / \mathrm{ha} \\
\text { Mesotrione } 800 \mathrm{ml} / \mathrm{ha} \\
\text { Mesotrione } 1333.33 \mathrm{ml} / \mathrm{ha}\end{array}$ & $\begin{array}{l}35.00 \\
867.25 \\
938.00 \\
728.75 \\
878.25 \\
938.00\end{array}$ & $\begin{array}{l}18.96 \mathrm{c} \\
29.32 \mathrm{ab} \\
30.59 \mathrm{a} \\
29.51 \mathrm{ab} \\
29.51 \mathrm{ab} \\
30.48 \mathrm{a}\end{array}$ & $\begin{array}{l}19.81 \mathrm{c} \\
55.06 \mathrm{~b} \\
61.90 \mathrm{ab} \\
55.22 \mathrm{~b} \\
60.85 \mathrm{ab} \\
67.90 \mathrm{a}\end{array}$ & $\begin{array}{l}2.33 \mathrm{c} \\
6.13 \mathrm{~b} \\
7.52 \mathrm{ab} \\
6.46 \mathrm{~b} \\
7.19 \mathrm{ab} \\
8.29 \mathrm{a}\end{array}$ & $\begin{array}{l}12.82 \mathrm{a} \\
12.45 \mathrm{a} \\
13.28 \mathrm{a} \\
12.89 \mathrm{a} \\
13.47 \mathrm{a} \\
13.28 \mathrm{a}\end{array}$ \\
\hline $\begin{array}{l}\text { Mean } \\
\text { CV }(\%) \\
\text { S.e.d }(\mathrm{df}=15) \\
\text { e.s.e }(\mathrm{Sx})\end{array}$ & & \begin{tabular}{r|}
27.64 \\
5.40 \\
1.48 \\
0.74 \\
\end{tabular} & $\begin{array}{r}53.50 \\
9.80 \\
5.24 \\
2.62 \\
\end{array}$ & $\begin{array}{l}6.32 \\
13.20 \\
0.84 \\
0.42 \\
\end{array}$ & $\begin{array}{l}13.03 \\
3.70 \\
0.48 \\
0.24 \\
\end{array}$ \\
\hline
\end{tabular}

Between Chlorimuron -ethyl $250 \mathrm{~g} / \mathrm{ha}$, mesotrione $800 \mathrm{ml} / \mathrm{ha}$ and Mesotrione 1333,33 ml/ha there is no significance difference and they led to a yield icrease of $212,47 \% ; 207,17 \%$ and $242.76 \%$ respectively. There are the same trends according to the quantity of extractible sugar. The average affect of herbicides $(7.37 \mathrm{~T} / \mathrm{ha})$ is an increase of $216,31 \%$ in comparison with untreated control. Between Chlorimuron - ethyl $250 \mathrm{~g} / \mathrm{ha}$, mesotrione $800 \mathrm{ml} / \mathrm{ha}$ and Mesotrione $1333,33 \mathrm{ml} / \mathrm{ha}$ there is no significant difference and they led to a quantity of extractible sugar increase of 222. $75 \% ; 208.58 \%$ and $255.79 \%$ respectively. According to sucrose content criteria there is no significant difference between the studied objects.

\subsection{Correlations between some studied parameters.}

Studied Correlations between the number of weeds and the number of machinable canes; between the weeds dry biomass and the number of machinable canes at the 30th and at the 90th days after herbicides application, clearly show that the yield of sugarcane decreases when weeds increase in number and weight of weeds dry biomass (Figure 1, 2, 3,4). 
Figure 1: correlation between the number of weeds the number of machinables canes at 30th day.
Figure 2: correlation between weeds dry biomass and the and number of machinables canes at 30th day.
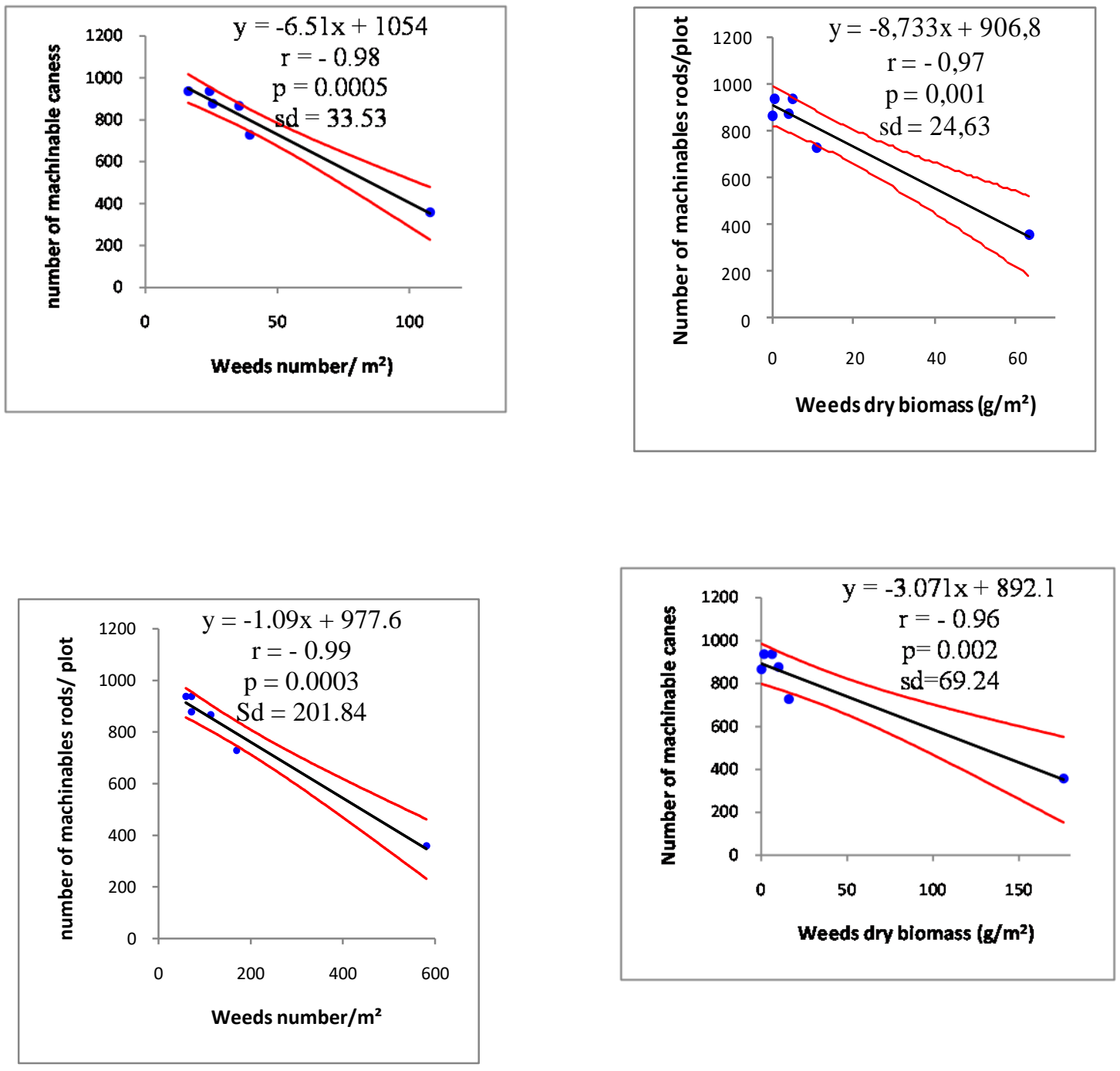

Figure 3: correlation between the weeds number and the number of machinables canes at 90th day figure 4: correlation between weeds dry biomass and the number of machinables canes at 90th day.

\section{DISCUSSION}

The results of this study, however, did not reveal cases of mesotrione phytotoxicity on sugar cane. This show that this sugar cane variety has some enzymes which are able to degraded Mesotrione active ingredients. Weeds negatively affect the sugar cane yield (CIRAD 2005). 
This negative affection, as shown by the correlations between some studied factors and the number of machinable rods, begins at the $30^{\text {th }}$ day after application and extends until $90^{\text {th }}$ day after application. The correlations between the studied factors (numbers of weeds, dry biomass of weeds) and the yield components as machinables rods gave negative coefficients correlation at the $30^{\text {th }}, 90^{\text {th }}$ day after herbicides application. These results are in line with those of Antoir et al, (2016) who, after conducting trials, to evaluate the weed's harmful effects on sugar cane yields in the Reunion island, stated that, from the second month of cultivation when a plot is totally grassed, the loss of cane yield is $300 \mathrm{~kg}$ to $500 \mathrm{~kg} / \mathrm{ha} /$ day; a loss of 9 to $15 \mathrm{~T}$ / ha for one month of weeding delay. These same tests showed that after four months, if the canopy is closed, the emergence of new weeds no longer affected sugarcane production. Marion et al. (1991); Marnotte and al. (2008) showed that sugar cane is very vulnerable to weeds during the first months of cultivation until the closure of the canopy, with yield losses of up to $15 \mathrm{~T} /$ month of competition.

The more or less slow recovery of weeds (15th day after application) may be due in part to the quality of the plowing performed but especially to the long duration of action and the efficiecy of herbicides. Indeed Mesotrione is a herbicide that belongs to the family of Callistemones. The active ingredient has a foliar activity, root, anti-germinative and is transferred quickly into the plant by root system. It works by blocking the HPPD enzyme in the chloroplasts which causes a bleaching of these weeds. It is effective on a broad range of broadleaf weeds as well as on some annual grasses (ACTA, 2014). These herbicides have significantly reduced the number of weeds in the plots, as showed by the weeds reduction that have ranged from 62.01 to $100 \%$. The same is true for dry biomass weeds. However, some weed species as Ageratum conyzoides, Mitracarpus villosus and Commelina benghalensis have not been destroyed by these herbicides. This could be due to a resistance effect of these weeds on herbicides. The Bourgeois et al. (2002) explain this situation on the one hand, by the fact that these species are not part of the efficiency spectrum of the product used and on the other hand, by the fact that some individuals of these species have not affected by the product at the time of spraying. These results are increased by a CIRAD test network set up on the island of REUNION in 2005, which tested the efficiency of several active ingredients including mesotrione on sugar cane. Their results show relative resistance of some weeds as Bidens pilosa and Ageratum conyzoides. The excess yield of Chlorimuron -ethyl $250 \mathrm{~g} / \mathrm{ha}$, control product $(+5.70 \%)$ over the recommended rate of Mesotrione $800 \mathrm{ml} /$ ha could be explained by the fact that, unlike Mesotrione where three (3) species of weeds were resistant, Chlorimuron ethyl of the family of sulfenylureas was effective against most species present except two namely Ageratum conyzoides and Commelina benghalensis. This has allowed him to reduce the incidence of competition of these weeds from cane plants, on the occupation of space and the removal of nutrients from the soil. For this purpose, Spanisha et al. (2017) propose that beyond its broad spectrum of action, mesotrione should be supplemented with other active ingredients to obtain a broader spectrum controlling both, the main dicotyledons and grasses. Nevertheless, the different rates of mesotrione made it possible to obtain an excess of machinable rods ranging from 42.14 to $60.67 \%$ and yieds increase in comparison to the untreated control.

\section{CONCLUSION}

The different herbicides applied negatively affected the development of weeds as well as the weight of their dry biomass. Some weeds such as broadleaf weeds have been greatly reduced, 
while others have shown some resistance to the image of Ageratum conyzoides, Mitracarpus villosus and Commelina benghalensis. The different doses of Amazing 480 SC studied were also not phyto-toxic for sugar cane plants. In addition, these different doses had a positive impact on the yield components, thus making it possible to obtain $42.14 \%$ surplus of machinable canes at a dose of $400 \mathrm{ml} / \mathrm{ha}$, and $55.64 \%$ at the recommended dose (Amazing $800 \mathrm{ml} / \mathrm{ha}$ ) and $60.76 \%$ at the higher dose (Amazing $1333.33 \mathrm{ml} / \mathrm{ha}$ ) compared to the untreated control. Amazing $480 \mathrm{SC}$, for reasons of economic profitability could therefore be applied at the rate of $800 \mathrm{ml} / \mathrm{ha}$.

\section{REFERENCES}

ACTA. (2014). Index phytosanitaire ; 50 ème édition, Paris, 956p.

AFPP-CEB. (2015). Liste des méthodes publiées par la commission des essais biologiques. France, 36p.

Akobundu I. O. et Agyakwa C. W (1982). Guides des adventices de l'Afrique de l'ouest. ISBN .978-131-036-520p.

Antoir J., Goebel F-R., Le Bellec F., Esther J.J., Maillary L., Mansuy A., Marion D., Marnotte P., Martin J., Rossolin G., Vincenot D. (2016). Les bonnes pratiques de désherbage de la canne à sucre - Ile de La Reunion. Chambre d'agriculture de La Reunion. 86p.

Berhaut J. (1967). Flora of Senegal. Claire Edition. Africa. Dakar. 485p.

Cirad. (2005). Production de références pour le désherbage de la culture de canne à sucre sur l'ile de la Réunion, réseau herbicides. 162p.

Dospiehov B.A. (1985). Field experimentation methods. Kolos. Moscow. 416p.

Goebel F-R., Way M. (2003). Investigation of the impact of Eldana saccharina (Lepidoptera: Pyralidae) on sugarcane yield in field trials in Zululand. Proceedings of the Annual Congress of the South African Sugar Technologists' Association, 77: 256-265.Annual Congress of the South African Sugar Technologists' Association (SASTA). 77, Durban, South Africa, August 19 - 22, 2003.

Hatil, E., Mauranyapin J.P., Marnotte P. (2008). Observations de l'enherbement en culture de canne à sucre en Guadeloupe, 4ème rencontre Internationale Francophone de ARTAS-AFCAS. Guadeloupe. France. 13p

Kambou G and Ouattara B. (2015). Herbicidal Activity of Chlorimuron-ethyl (107 g/kg) Associated with Metribuzin (643 g/kg) on Sugar Cane Weeds and Its Effects on Soil Agrochemical Properties, in Burkina Faso. Journal of environmental science and engineering B. Vol.4 (9): 501-512.

Kambou G and Ouattara B. (2016). Biological efficiency of hexazinon on sugar cane weeds and its effects on soil agrochemical properties, in Burkina Faso. International Journal of Agricultural Policy and Research. Vol4 (1):7-16.

Kambou G., Millogo N., Tiala A. (2008). Activité herbicide de l'Hexazinone sur les adventices de la canne à sucre en repousses. Rapport de campagne sucrière, projet SAVANA, 21p.

Likov A.M., Tulikov A.M. (1985). Weed science practical handbook based on pedology.. Moscow. USSR. Agropromizdat. 207p.

Le Bourgeois T., Marnotte P. (2002). La lutte contre les mauvaises herbes. In Cirad-Gret-MAE [ed.], Mémento de l'agronome, Montpellier, France. 663-684. 
Marion D., Marnotte P. (1991). Nuisibilité de l'enherbement sur une culture de canne à sucre. Coll. AFCAS. 1ère rencontre Int en langue française sur la canne à sucre. Montpellier France. 188-191.

Marnotte P. (2008). La gestion des enherbements en culture de canne à sucre. Améliorer le désherbage dans le respect de l'environnement. CIRAD-PERSYST-UPR Systèmes canniers. Montpellier. 2p.

Terry P. J. (1983). Quelques adventices banales des cultures de l'Afrique occidentale et la lutte contre celles-ci. Incata Press. Melbourne. Australia. 132p.

Vilistky. I. N. (1989). Technologies of herbicides use. L. Agropromizdat . 176p. 